1 ANALYTICAL SCIENCE

7 \& TECHNOLOGY

Vol. 26, No. 6, 395-400, 2013

http://dx.doi.org/10.5806/AST.2013.26.6.395

\title{
A solid-state NMR study on the hydration effect on the lipid phase change in the presence of an antimicrobial peptide
}

\author{
Chul Kim ${ }^{\star}$
}

Department of Chemistry, Hannam University, Daejeon 305-811, Korea

(Received September 2, 2013; Revised December 2, 2013; Accepted December 2, 2013)

\section{항균성 펩타이드와 혼합된 인지질 분자의 상 변화에 있어서 수화 효과에 대한 고체 핵자기 공명 연구}

\section{김 철*}

한남대학교 화학과

(2013. 9. 2. 접수, 2013. 12. 2. 수정, 2013. 12. 2. 승인)

\begin{abstract}
The hydration and antimicrobial peptide effects on the lipid alignment on the surface of a thin glass plate were investigated by using the solid-state nuclear magnetic resonance spectroscopy. Pure 1-palmitoyl-2oleoyl-sn-glycero-3-phosphotidylcholine (POPC) lipid molecules were well aligned on the surface of a thin glass plate without direct hydration by placing the sample for a few days in the desiccator containing a saturated sodium phosphate dibasic solution, which provided $95 \%$ relative humidity. But there was a big difference between two lipid phases, the one of which was hydrated by placing the sample for a few days in the desiccator with $95 \%$ relative humidity without direct hydration and the other was directly hydrated by dropping water and then placed for a few days in the same desiccator. The surface mobility of POPC molecules in a lipid bilayer phase was much activated by water. While the time for the POPC to align on the glass plate surface was short, the time for the PG-1/POPC mixture to reach the its equilibrium state was long.

요 약: 얇은 유리판 위에서 자동적으로 정렬되는 인지질 분자의 정렬도에 대한 수분 및 항균성 펩타이 드의 효과를 고체 핵자기 공명 분광법을 이용하여 조사하였다. 순수한 1-palmitoyl-2-oleoyl-sn-glycero-3phosphotidylcholine (POPC) 인지질 만을 유리판 위에서 정렬시킬 때에는 직접적인 물의 투입 없이 $95 \%$ 상대 습도에서 수일간 수화시키는 것만으로 충분했다. 하지만, protegrin-1 (PG-1)과 같은 항균성 펩타이 드가 혼합되어 있는 인지질의 경우에는 $95 \%$ 의 상대 습도에서 수일간 수화시키는 것과 약간의 물을 시 료에 직접 투입하여 수화시키는 것이 크게 달라진다는 것을 확인하였다. 충분한 양의 물이 투입되었을 때, 지질 이중막 위에서 인지질 분자들의 표면 움직임이 매우 활발하였다. 순수한 POPC 분자들이 얇은 유리판 위에서 정렬되는 시간에 비해 항균성 펩타이드가 혼합되어 있는 경우에는 POPC 분자들이 평형 상을 이루어질 때까지는 상당한 시간이 필요함을 확인하였다.
\end{abstract}

Key words: antimicrobial peptide, protegrin-1, lipid bilayer, hydration effect, solid-state NMR

Corresponding author

Phone : +82-(0)42-629-8875 Fax : +82-(0)42-629-8811

E-mail : chulkim@hnu.kr 


\section{1. 서 론}

고등 생물이 분비하는 면역 분자들 중의 하나인 항 균성 펩타이드들의 활성을 이해하기 위한 많은 연구 들이 지금까지 진행되어오고 있다. ${ }^{1-4}$ 이 펩타이드들은 특정한 수용 단백질의 도움 없이 세균의 세포막에 직 접 작용하여 세포막을 파괴시키는 작용을 하는 것이 특징이다. ${ }^{5}$ 이들의 작용 반응성은 펩타이드의 2 차원 구조 $(\alpha \text {-helix 또는 } \beta \text {-sheet })^{6}$ 펩타이드의 농도 및 표면 전하 밀도, ${ }^{7}$ 지질의 종류 ${ }^{8}$ 등에 의해 달라진다. 이러한 변수들에 대한 영향을 확인하기 위해서 원편광 이색 성 분광법(circular dichroism, $\mathrm{CD}),{ }^{9,10}$ 형광 분광법 (fluorescence), ${ }^{9,11}$ 등과 함께 고체 핵자기 공명 분광법 (solid-state nuclear magnetic resonance) ${ }^{12}$ 이 널리 쓰이 고 있다.

고체 $\mathrm{NMR}$ 에 의한 연구의 경우, 항균성 펩타이드와 지질막의 상호작용 시 지질막에 대한 펩타이드의 배 향 및 지질 분자들의 공간적 배향에 대한 연구가 주 를 이루고 있다. ${ }^{13-15}$ 이러한 연구를 위해서는 펩타이드 와 지질 혼합물을 얇은 유리판에 떨어뜨리고 수화시 킨 후, 지질 이중막의 정렬도를 다양한 핵종의 스펙트 럼으로 확인한다. ${ }^{16,17}$ 문제는 이러한 실험 방법에 있어 서 얇은 유리판에 펩타이드/지질 혼합물을 도포하는 과정에 의해 지질 분자들의 정렬도가 달라진다는 것 이다. 본 논문의 저자는 이전 논문에서 이와 같은 시 료의 제조 과정에 대한 새로운 접근을 시도한 바 있 다. ${ }^{18}$ 즉, 하나의 유리판에 잘 정렬된 지질 이중막을 만들고 다른 유리판에는 항균성 펩타이드를 올려 놓 은 다음, 두 유리판을 겹쳐서 항균성 펩타이드가 지질 이중막에 작용하게 한다. 이 후 작용 시간에 따라 지 질 이중막의 정렬도가 파괴되는 과정을 지질 분자의 ${ }^{31} \mathrm{P}$ 고체 $\mathrm{NMR}$ 스펙트럼을 측정하여 살펴보았다. 새 롭게 시도된 시료 제조 과정을 통해 펩타이드와 지질 을 균일하게 섞어주는 기존 방식에서 얻어진 고체상 과 상이한 펩타이드-지질 고체상이 얻어지는 것을 확 인하기도 하였다. 다른 논문에서는 항균성 펩타이드가 혼합된 지질 이중막이 얇은 유리판 표면에서 정렬되 고, 특정 구조체를 만들어 가는 과정을 ${ }^{2} \mathrm{H}$ 고체 $\mathrm{NMR}$ 스펙트럼을 통해 확인하기도 하였다. ${ }^{19,20}$

본 연구에서는 돼지의 백혈구 등에서 발견되며 18 개의 아미노산으로 이루어진 protegrin-1 (PG-1, MW $=2154 \mathrm{Da})^{21}$ 이라는 항균성 펩타이드가 $\mathrm{POPC}$ 지질 분자의 상변화에 어떠한 영향을 주는지를 시료의 수 화 과정을 달리하면서 파악하고자 하였다. PG-1은 다
양한 세균과 곰팡이에 대한 항균 작용은 물론, HIV-1 에 대한 항바이러스 효과도 보여주고 있어 매우 관심 이 가는 펩타이드 중의 하나이다. ${ }^{22}$ 여러 연구에 의하 면, PG-1은 생체막에 있는 인지질 분자의 종류, 펩타 이드의 농도 등에 의해 기공구조를 만들 수도 있고, 때론 생체막을 얇게 만드는 효과만을 낼 수도 있는 것으로 알려져 있다. ${ }^{13,23-27}$

\section{2. 실 험}

\section{1. 시약}

1-Palmitoyl-2-oleoyl-sn-glycero-3-phosphotidylcholine (POPC)는 Avanti Polar Lipids Inc. (Alabaster, AL, USA) 로부터, 항균성 펩타이드 protegrin-1은 GL Biochem (Shanghi, China)으로부터 구입하여 추가 정제 과정 없이 사용하였다. Trifluoroethanol (TFE), chloroform, 그리고 sodium phosphate dibasic 등은 Aldrich Chemicals (Milwaukee, WI, USA)로부터 구입하여 사용하였다. 고체 NMR 스펙트럼 측정을 위한 시료를 제조하기 위하여 가로와 세로의 길이가 각각 $10 \mathrm{~mm}$ 인 얇은 유리 판을 Marienfeld Laboratory Glassware (Bad Mergentheim, Germany)로부터 구입하여 사용하였다.

\section{2. 시료 제조}

지질 이중막이 얇은 유리판 사이에서 자동적으로 정렬되어가는 과정을 확인하기 위해서 다음과 같은 과정을 거쳤다. $4.8 \mathrm{mg} \mathrm{POPC}$ 지질을 $\mathrm{TFE} /$ chloroform $(2 / 1, v / v)$ 용액에 녹인 후, 이 용액을 얇은 유리판에 떨어뜨린다. 시료를 공기 중에서 수시간 건조시킨 후, 진공 상태에서 밤새 건조시켜 지질 분자 사이에 남아 있는 극미량의 유기용매를 완전히 제거한다. 이렇게 건조된 시료를 sodium phosphate dibasic으로 포화된 용액이 들어있는 데시케이터 안에서 약 2 일 동안 방 치해둔다. ${ }^{28}$ 이 과정에 의해 유리판 표면에 있는 지질 분자들은 $95 \%$ 의 상대습도에서 수화될 것이다. ${ }^{29}$ 제조 된 유리판 시료 10 개 정도를 포개어 준다. 포개어진 유리판을 Parafilm으로 싸고, polyethylene으로 밀봉하 여, ${ }^{31} \mathrm{P}$ 고체 $\mathrm{NMR}$ 스펙트럼을 측정하는 동안 시료가 마르지 않도록 한다.

두번째 시료는 첫번째 시료의 제조 방법과 같으나, 데시케이터 안에서 방치해 두기 전에 약 $2 \mu \mathrm{L}$ 의 물을 시료에 직접 첨가하여 수화시킨다. 이 후 과정은 첫번 째 경우와 동일하다.

세번째 시료는 TFE/chloroform 용매에 PG-1 펩타이 
드와 $\mathrm{POPC}$ 를 그 구성비가 $1 / 20(\mathrm{PG}-1 / \mathrm{POPC})$ 이 되도 록 녹인다. 얇은 유리판에 시료를 떨어뜨린 후 용매를 건조시킨다. 위의 언급한 것과 동일한 데시케이터 안 에서 지질막을 수화시킨다. $95 \%$ 상대 습도에서 수화 된 PG-1/POPC 혼합물의 ${ }^{31} \mathrm{P}$ 고체 $\mathrm{NMR}$ 스펙트럼을 얻는다. 스펙트럼을 얻은 후, 밀봉을 제거한다. 약 2 $\mu \mathrm{L}$ 의 물을 시료에 직접 투입한다. 재밀봉한 시료를 시간에 따라 ${ }^{31} \mathrm{P}$ 고체 $\mathrm{NMR}$ 스펙트럼을 얻는다.

\section{3. 고체 핵자기 공명 분광법}

${ }^{31} \mathrm{P}$ 고체NMR 스펙트럼은 Bruker MSI-300 분광기 를 이용하여 측정하였다. ${ }^{31} \mathrm{P}$ 스펙트럼의 화학 이동값 (chemical shift)의 기준은 $85 \% \mathrm{H}_{3} \mathrm{PO}_{4}$ 수용액으로부터 나오는 신호를 $0 \mathrm{ppm}$ 으로 정하였다. ${ }^{31} \mathrm{P}$ 의 $90^{\circ}$ 펄스 길이는 $5 \mu \mathrm{s}$ 이고, 수소핵과의 쌍극자-쌍극자 상호작용 을 없애기 위해 사용한 디커플링(decoupling) radio frequency 자기장의 세기는 $45 \mathrm{kHz}$ 이었다. 스펙트럼의 폭은 $17.86 \mathrm{kHz}$ 이었고, 2000 번의 반복측정을 통하여 스펙트럼을 얻었다. 고체 $\mathrm{NMR}$ 스펙트럼의 측정온도 는 $25^{\circ} \mathrm{C}$ 이었다.

\section{3. 결과 및 고찰}

\section{1. 수화에 의한 $\mathrm{POPC}$ 분자들의 정렬}

Fig. 1에 보이는 ${ }^{31} \mathrm{P}$ 고체 NMR 스펙트럼은 순수한 $\mathrm{POPC}$ 만을 유리판 위에 올려놓은 후 다양한 방법으로 $\mathrm{POPC}$ 지질 분자들을 수화시키면서 얻어진 것이다. Fig. 1(a)는 유리판 위의 $\mathrm{POPC}$ 를 $95 \%$ 상대습도를 가 지는 데시케이터 안에 수일간 놓아둔 후 측정한 스펙 트럼이다. Fig. 1(b)는 유리판 위의 POPC에 물 $2 \mu \mathrm{L}$ 를 직접 떨어뜨린 후 1 시간 이내에 곧바로 측정한 스 펙트럼이다. 그림에서 볼 수 있듯이 두 경우 모두 28 $\mathrm{ppm}$ 부근에서 하나의 신호만을 보여준다. 이러한 스 펙트럼이 의미하는 것은 POPC 분자들이 유리판 위에 서 수직방향으로 잘 정렬되어 있다는 것을 뜻한다. ${ }^{2}$ $-14 \mathrm{ppm}$ 에서 약간의 신호가 보이는 것은 정렬되어 있 지 않는 POPC 분자들이 소량 존재한다는 것을 말한 다. 두 경우를 통해 알 수 있는 것은 유리판 위에 $\mathrm{POPC}$ 분자들이 놓여있을 때, 이 지질 분자들을 $95 \%$ 상대습도 공기 중에서 수화시키나, 또는 직접 물을 가 하여 충분히 수화시키나, POPC 분자가 유리판 위에 서 잘 정렬한다는 것이다.

Fig. 1(c)는 유리판 위의 $\mathrm{POPC}$ 에 물 $2 \mu \mathrm{L}$ 를 직접 떨어뜨린 후 데시케이터 안에서 하루동안 놓아둔 후

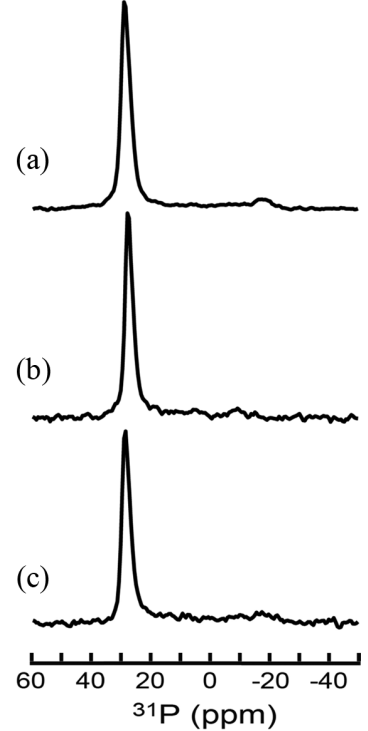

Fig. 1. Experimental ${ }^{31} \mathrm{P}$ solid-state NMR spectra of POPC multi-bilayers aligned on the thin glass plate. The samples were (a) hydrated at $95 \%$ relative humidity without direct hydration, (b) directly hydrated, and (c) directly hydrated and then incubated for 1 day at $95 \%$ relative humidity.

측정한 스펙트럼이다. 이 스펙트럼 또한 $(\mathrm{A})$ 와 $(\mathrm{B})$ 스 펙트럼과 거의 같다는 것을 확인할 수 있다. 특히, 28 $\mathrm{ppm}$ 부근에서 나오는 신호의 선폭을 보면 세가지 경 우 거의 같다는 것을 확인할 수 있다. 이 선폭은 $\mathrm{POPC}$ 분자들의 정렬도와 운동성의 정도에 의해 달라 진다. 세가지 경우 모두 동일하다는 것은 유리판 위에 서 지질 분자들의 거의 동일한 수준으로 정렬되어 있 으며, 그 분자들의 운동성 또한 충분히 활발하다는 것 을 의미한다.

\section{2 수화에 의한 PG-1/POPC 혼합물의 상 변화}

Fig. 2에서 보여주는 스펙트럼은 PG-1/POPC ( $1 / 20$, 몰비율) 혼합물을 유리판 위에 올려 놓고서 측정한 ${ }^{31} \mathrm{P}$ 고체 NMR 스펙트럼이다. Fig. 2(a)의 가장 위쪽에 있는 스펙트럼은 유리판 시료에 물을 직접 주입하지 않은 상태에서 $95 \%$ 상대습도를 가지는 데시케이터 안에서 수일간 수화시킨 후, 얻은 스펙트럼이다. 반면 에 $2 \mathrm{~A}$ 의 두번째부터 다섯번째까지의 스펙트럼은 유리 판 위의 시료에 $2 \mu \mathrm{L}$ 의 물을 직접 떨어뜨린 후, 각각 1 시간, 13 시간, 37 시간, 60 시간 동안 데시케이터 안 에서 보관한 후에 측정한 스펙트럼이다. 그림에서 볼 수 있듯이 직접적인 수화에 의해 $\mathrm{POPC}$ 분자들의 고 
(a)

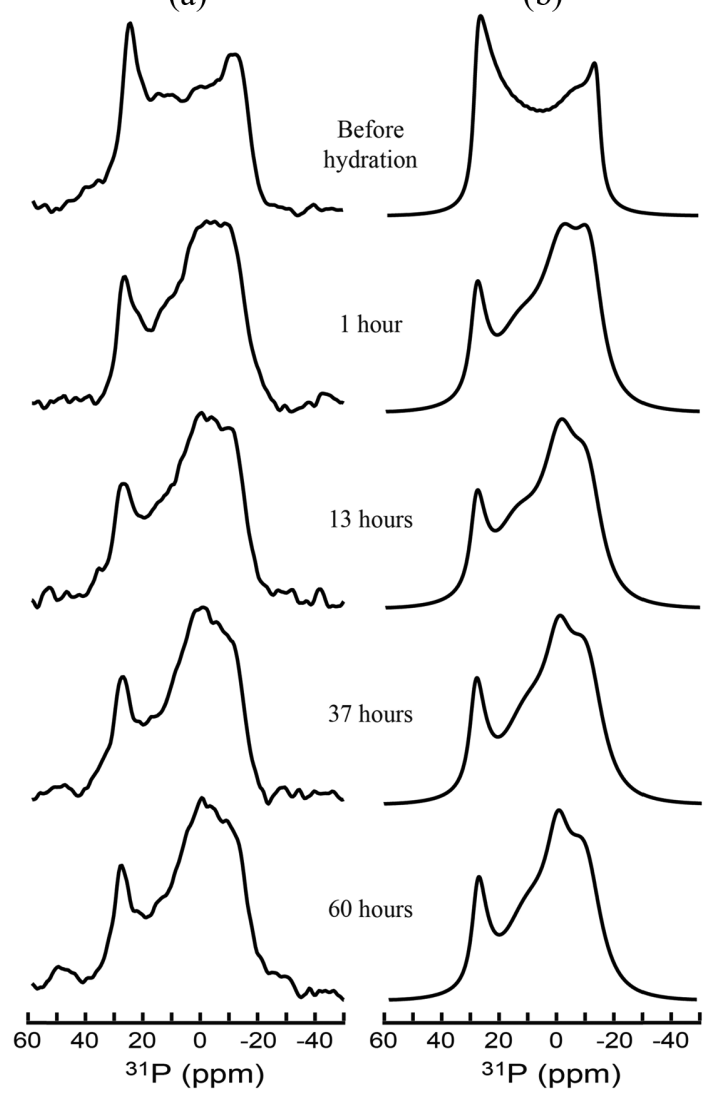

Fig. 2. (a) Experimental and (b) simulated ${ }^{31} \mathrm{P}$ solid-state NMR spectra of POPC multi-bilayers distorted by protegrin-1. The spectra were obtained with the samples: (the top spectra) hydrated at $95 \%$ relative humidity without direct hydration, (the second to fifth spectra) directly hydrated and then incubated for 1 hour (the second spectra), 13 hours (the third spectra), 37 hours (the fourth spectra), and 60 hours (the fifth spectra).

체상이 크게 달라지는 것을 알 수 있다. 이러한 고체 상의 변화는 측정된 스펙트럼을 몇가지 고체상의 조
합으로 모사함으로써 자세히 파악할 수 있다.

일반적으로PG-1은 지질 이중막에 작용하여 원환체 기공(toroidal pore)을 만드는 것으로 알려져 있다. ${ }^{17,23}$ 물론 경우에 따라서는 등방상 (isotropic phase)을 형성 하기도 한다. ${ }^{19}$ Fig. 2(b)의 스펙트럼은 측정된 스펙트 럼 $2 \mathrm{~A}$ 를 가장 잘 설명해주는 지질 고체상으로 모사한 결과이다. Fig. 2(b)는 모두 3가지의 고체상이 존재하 는 것으로 가정하여 모사한 것들이다. 단지, 2 개의 고 체상이 존재하는 것으로는 실험적으로 측정된 스펙트 럼 $(2 \mathrm{~A})$ 를 충분히 설명해주지 못하기 때문이다. Table 1 에는 모사한 스펙트럼에 대한 각 고체상의 백분율 및 고체상 안에서 POPC 분자들의 운동성을 말해주는 변수들이 나타나 있다.

첫번째 특징을 살펴보면, $28 \mathrm{ppm}$ 에 나오는 신호의 선폭이 수화 시간이 지남에 따라 크게 줄어들었다는 점이다. 또한 선의 대칭성도 증가하였다. 이 신호는 유리판 위에서 수직으로 잘 정렬된 $\mathrm{POPC}$ 분자로부터 얻어지는 신호로서 선폭이 줄어들고, 대칭성이 증가하 였다는 것은 분자들의 정렬도가 증가하였음을 말해준 다. Table 1에서 보는 바와 같이, 이중막 구조의 Mosaic 분포의 표준편차가 $20^{\circ}$ 에서 $12^{\circ}$ 로 줄어들었다는 사실 로 확인할 수 있다.

두번째 특징은, 시간이 지남에 따라 $0 \mathrm{ppm}$ 의 신호 세기는 증가하고, $-14 \mathrm{ppm}$ 의 신호 세기는 감소한다는 것이다. 그 증감의 정도가 크지는 않지만, 변하였다는 사실은 측정된 스펙트럼을 모사함으로써 확실히 알 수 있었다. $0 \mathrm{ppm}$ 에서 나오는 신호는 일반적으로 등 방상으로부터 얻어지는 것이며, $-14 \mathrm{ppm}$ 에서 나오는 신호는 PG-1에 의해 생성된 원환체 기공으로부터 얻 어지는 것이다. 모사된 결과를 보면 $0 \mathrm{ppm}$ 신호의 증 가는 등방상 구조를 나타내는 고체상의 증가로써가 아니라 등방상 구조의 회전 확산 속도의 증가로부터 기인한다는 것이다. 이는 수화 초기에 형성된 등방상 의 크기가 수화시간이 지남에 따라 감소하는 것으로

Table 1. Percentages of POPC phases distorted by protegrin-1

\begin{tabular}{lccccc}
\hline \hline \multirow{2}{*}{ Phases } & Before hydration & \multicolumn{3}{c}{ Storage times } \\
\cline { 3 - 6 } & & 1 hour & 13 hours & 37 hours & 60 hours \\
\hline Bilayer & $10\left(20^{\circ}\right)^{\mathrm{a}}$ & $14\left(12^{\circ}\right)^{\mathrm{a}}$ & $13\left(12^{\circ}\right)^{\mathrm{a}}$ & $15\left(12^{\circ}\right)^{\mathrm{a}}$ & $15\left(12^{\circ}\right)^{\mathrm{a}}$ \\
Pore & $50\left(20^{\circ}\right)^{\mathrm{a}}$ & $55(3.0)^{\mathrm{c}}$ & $58(4.0)^{\mathrm{c}}$ & $67(5.0)^{\mathrm{c}}$ & $67(5.0)^{\mathrm{c}}$ \\
Isotropic & $40(1.5)^{\mathrm{b}}$ & $31(1.6)^{\mathrm{b}}$ & $29(2.0)^{\mathrm{b}}$ & $19(3)^{\mathrm{b}}$ & $19(3.5)^{\mathrm{b}}$ \\
\hline
\end{tabular}

The standard deviation for an angular Gaussian spread of bilayer normal.

${ }^{\mathrm{b}}$ The rotational diffusion coefficient of an isotropic structure with a diameter of $20 \AA$. The unit is $10^{-14} \mathrm{~m}^{2} / \mathrm{s}$.

'The lateral diffusion coefficient on an elliptical toroidal pore surface in the lipid bilayer. The unit is $10^{-14} \mathrm{~m}^{2} / \mathrm{s}$. The ratio between the semiminor and semimajor distances of the ellipse is $0.55 .^{17}$ 
이해할 수 있다.

세번째 특징은 원환체 기공 구조체의 증가와 지질 분자들의 운동성의 증가에 의한 스펙트럼의 변화이다. 초기에 약 $50 \%$ 정도를 차지하는 기공구조체가 수화 시간이 지남에 따라 $67 \%$ 까지 증가하였다는 것이다. 아울러, 원환체 기공 내에서의 지질 분자들의 표면 확 산 계수 $\left(D_{\mathrm{ld}}\right)$ 도 증가하였다는 것이다. 똑같은 원환체 기공으로부터 얻어진 신호라고 할지라도 원환체 기공 내에서 지질 분자들의 표면 확산속도가 달라지면 ${ }^{31} \mathrm{P}$ 고체 NMR 스펙트럼 상에서의 신호 모양이 달라지게 된다는 사실로부터 지질 분자들의 표면 확산계수를 얻게 된다. 이것에 대한 자세한 논의는 저자가 발표한 이전 논문에 잘 나와있다. ${ }^{17}$ 수화시간이 늘어남에 따 라 원환체 기공구조가 안정화되어지고 기공내부의 수 화 상태가 잘 정리됨에 따라 지질 분자들의 움직임이 조금 더 활발해지는 것으로 이해된다.

마지막으로 알 수 있는 사실은, 직접 수화시킨 후 37 시간 이후에는 유리판 위의 PG-1/POPC 혼합물의 고체상이 평형에 이르러 있다는 것이다. 그것은 37 시 간 후와 60 시간 후에 측정한 ${ }^{31} \mathrm{p}$ 고체 $\mathrm{NMR}$ 스펙트럼 의 변화가 거의 없다는 것을 통해 확인할 수 있었다.

\section{4. 결 론}

얇은 유리판 위에서 자동적으로 정렬하는 POPC 지 질 분자의 정렬 과정이 수화정도, 수화시간 등에 의해 어떻게 달라지는 지 확인하였다. 순수한 POPC 지질 분자를 $95 \%$ 상대습도를 가지는 데시케이터 안에서 수화시킬 때, 물을 지질 분자에 직접 넣어주는 것의 효과가 거의 없었다. 즉, 물을 직접 주입하지 않아도 $\mathrm{POPC}$ 지질 분자는 유리판 위에서 잘 정렬하였다.

그러나 PG-1이 포함된 $\mathrm{POPC}$ 지질 분자의 경우에 는 직접적인 물의 주입이 $\mathrm{POPC}$ 지질 분자의 상 변화 에 영향을 준다는 것을 확인하였다. $95 \%$ 상대습도를 가지는 데시케이터 안에서 수화시킨 PG-1/POPC 혼합 물의 상은 최소한 3 개 이상이었다. 그리고, 그러한 상 에서의 지질 분자의 움직임은 매우 작았다. 하지만, 유리판 사이에 놓여진 펩타이드-지질 혼합물에 소량의 물을 투입하였을 때, 상의 변화가 일어나기 시작했고 지질 분자들의 움직임이 활발해지는 것을 확인했다. 물 의 투입 후 혼합물이 물리화학적인 평형상태에 이르는 데는 37 시간 이상이 소요되는 것을 확인하였다.

이와 같은 결과는 얇은 유리판 위에서 자동적으로 정렬되어지는 모델 생체 지질막을 이용한 실험을 행
하는 경우에 있어서 물리화학적 평형에 이르렀는가에 대한 확인과 함께 지질막에 포함된 수분양에 따라 모 델 생체 지질막을 이루는 지질 분자들의 물리적인 특 성이 달라진다는 사실을 주의해야 함을 말해준다 하 겠다. 지질의 종류와 펩타이드의 종류 및 수화 과정에 의한 지질막의 특성변화에 대한 연구가 계속될 것이 다.

\section{감사의 글}

본 연구는 2013년도 한남대학교 교비 학술 연구 조 성비 지원에 의해 이루어졌으며 이에 감사드립니다.

\section{참고문헌}

1. J. J. Buffy, A. J. Waring and M. Hong, J. Am. Chem. Soc., 127(12), 4477-4483 (2005).

2. K. J. Hallock, D. K. Lee and A. Ramamoorthy, Biophys. J., 84(5), 3052-3060 (2003).

3. P. M. Hwang and H. J. Vogel, Biochem. Cell Biol., 76(2/3), 235-246 (1998).

4. M. Zasloff, Proc. Natl. Acad. Sci. USA, 84(15), 54495453 (1987).

5. M. R. Yeaman and N. Y. Yount, Pharmacol. Rev., 55(1), 27-55 (2003).

6. R. Mani, A. J. Waring, R. I. Lehrer and M. Hong, Biochim. Biophys. Acta, Biomembr, 1716(1), 11-18 (2005).

7. Y. Bai, S. Liu, P. Jiang, L. Zhou, J. Li, C. Tang, C. Verma, Y. Mu, R. W. Beuerman and K. Pervushin, Biochemistry, 48(30), 7229-7239 (2009).

8. O. Toke, Biopolymers, 80(6), 717-735 (2005).

9. K. Matsuzaki, K.-I. Sugishita, N. Ishibe, M. Ueha, S. Nakata, K. Miyajima and R. M. Epand, Biochemistry, 37(34), 11856-11863 (1998).

10. Y. Herasimenka, M. Benincasa, M. Mattiuzzo, P. Cescutti, R. Gennaro and R. Rizzo, Peptides, 26(7), 11271132 (2005).

11. K. Matsuzaki, O. Murase, N. Fujii and K. Miyajima, Biochemistry, 34(19), 6521-6526 (1995).

12. J.-A. Richard, I. Kelly, D. Marion, M. Pezolet and M. Auger, Biophys. J., 83(4), 2074-2083 (2002).

13. S. Yamaguchi, T. Hong, A. Waring, R. I. Lehrer and M. Hong, Biochemistry, 41(31), 9852-9862 (2002).

14. B. Bechinger, Biochim. Biophys. Acta, Biomembr., 
1712(1), 101-108 (2005).

15. R. Mani, M. Tang, X. Wu, J. J. Buffy, A. J. Waring, M. A. Sherman and M. Hong, Biochemistry, 45(27), 83418349 (2006).

16. J. J. Buffy, M. J. McCormick, S. Wi, A. Waring, R. I. Lehrer and M. Hong, Biochemistry, 43(30), 9800-9812 (2004).

17. S. Wi and C. Kim, J. Phys. Chem. B, 112(36), 1140211414 (2008).

18. C. Kim and S. Wi, Bull. Korean Chem. Soc., 33(2), 426-432 (2012).

19. C. Kim, Bull. Korean Chem. Soc., 31(2), 372-378 (2010).

20. C. Kim, J. Korean Chem. Soc., 54(2), 183-191 (2010).

21. V. N. Kokryakov, S. S. Harwig, E. A. Panyutich, A. A. Shevchenko, G. M. Aleshina, O. V. Shamova, H. A. Korneva and R. I. Lehrer, FEBS Lett., 327(2), 231-236 (1993).

22. R. L. Fahrner, T. Dieckmann, S. S. L. Harwig, R. I.
Lehrer, D. Eisenberg and J. Feigon, Chem. Biol., 3(7), 543-550 (1996)

23. L. Yang, T. M. Weiss, R. I. Lehrer and H. W. Huang, Biophys. J., 79(4), 2002-2009 (2000).

24. J. J. Buffy, A. J. Waring, R. I. Lehrer and M. Hong, Biochemistry, 42(46), 13725-13734 (2003).

25. J. J. Buffy, T. Hong, S. Yamaguchi, A. J. Waring, R. I. Lehrer and M. Hong, Biophys. J., 85(4), 2363-2373 (2003).

26. R. Mani, J. J. Buffy, A. J. Waring, R. I. Lehrer and M. Hong, Biochemistry, 43(43), 13839-13848 (2004).

27. C. Kim, J. Spano, E. K. Park and S. Wi, Biochim. Biophys. Acta, 1788(7), 1482-1496 (2009).

28. K. J. Hallock, D.-K. Lee, J. Omnaas, H. I. Mosberg and A. Ramamoorthy, Biophys. J., 83(2), 1004-1013 (2002).

29. E. W. Washburn, C. J. West and C. Hull, 'International Critical Tables of Numerical Data, Physics, Chemistry, and Technology', McGraw-Hill, New York, 1926. 